\title{
"I Worry about My Community": African American Women Utilizing Communal Notions of Citizenship in the Social Studies Classroom
}

\author{
Amanda E. Vickery \\ Arizona State University \\ U. S. A.
}

\begin{abstract}
This qualitative multiple case study utilizes a Black feminist ethic of caring (Collins, 2009; Thompson, 1998) to explore how three African American women social studies teachers draw on their personal and community knowledge to conceptualize and teach the construct of citizenship to their students of color. Instead of conveying traditional notions of citizenship that value blind patriotism to the nation-state and individualism, they instead chose to teach citizenship as relational and centered on uplifting their cultural community. This study hopes to shed light on how critical notions of citizenship may be presented and utilized in classrooms.
\end{abstract}

KEYWORDS: cultural citizenship, Black feminism, ethic of caring, African American teachers, cultural community

The Changing Construct of Citizenship

Citizenship Education in the Classroom Methodology

Emerging Themes

Discussion and Recommendations

Notes

References

Author Contact

\section{The Changing Construct of Citizenship}

The construct of citizenship and what it means to be a citizen are complex ideals for which multiple manifestations exist within society; these manifestations have changed over the course of American history. Yuval-Davis (2006) wrote that the contemporary debate on citizenship deals with the question of who "belongs" and who does not, as well as what are the common grounds (in nationality, culture, race, gender, religion) that are required to signify belonging. Both history and contemporary society have paid witness to political, social, and economic structures using the politics of belonging to exclude certain marginalized groups from attaining citizenship status and rights because of their perceived differences. 
For centuries, American citizenship (as membership, participation, and a legal status) has become a racialized (Mills, 1997), gendered (Pateman, 1988), and classed (Zinn, 2003) construct. While citizenship is a legal status that gives citizens certain rights and privileges, it also becomes a social construct and discursive practice that has changed over time to exclude certain bodies from belonging and participating as legitimate members of the body politic. For example, African Americans ${ }^{1}$ have fought to prove their legitimacy as members of society within the United States since their first arrival at Jamestown in the seventeenth century. Although African Americans successfully achieved de jure citizenship as a result of the Fourteenth Amendment (1868) and the Civil Rights Act (1964), recent events have demonstrated that African Americans continue to be positioned outside the realm of de facto citizenship and do not, therefore, consistently enjoy the rights of due process and equal protection afforded other legitimate members of society.

Tillet (2012) used the phrase civic estrangement to describe the ways in which African Americans possess full legal citizenship yet continue to be marginalized in how they are represented in the American citizenship narrative and memory that promote an American identity. She wrote:

As a form of an ongoing racial inequality, civic estrangement describes the paradox post-civil rights African Americans experience as simultaneous citizens and "non-citizens," who experience the feeling of disillusionment and melancholia of non-belonging and a yearning for civic membership. (p. 3)

Spinner (1984) argued that traditional liberal citizenship had failed African Americans because it ignored three important tenets that impact how African Americans see themselves as citizens. Traditional citizenship (a) is premised on individual rights that had been denied to African Americans; (b) failed to acknowledge histories of oppression; and (c) did not recognize communal membership that is important lines of support in African American communities. These are all factors in how and why a double consciousness (DuBois, 1994), or dual sense of citizenship, continues to persist among many African Americans (Tillet, 2012). Civic estrangement leads to not only the development of a "double consciousness" in terms of a citizen identity, but also a search for a new site of citizenship where African Americans, and other historically marginalized groups, can redefine the notion of citizenship that better attends to their cultural historical knowledge.

Because of this purposeful omission of multiple histories, voices, and community knowledge, historically marginalized populations have taken it upon themselves to reconceptualize citizenship frameworks that are more inclusive and to recenter citizenship on communal/community membership in a way that recognizes cultural identity as being an integral aspect of citizenship (see Lomawaima \& McCarty, 2002; Rosaldo \& Flores, 1997). A number of scholars have written about cultural community membership as being a valid form of citizenship and a way by which historically marginalized groups have asserted themselves as citizens in public political spaces (Flores, 1997b; Ong, 1996; 
Rosaldo, 1994; Rosaldo \& Flores, 1997). Latina/o scholars introduced a cultural citizenship framework as an attempt to recognize their complex experience with citizenship in regards to culture, phenotype, representation, and language (Flores, 1997a; Rosaldo, 1994; Rosaldo \& Flores, 1997). Flores (1997b) argued that cultural citizenship should be thought of as a range of different everyday activities in which groups "claim space in society, define their community, and claim rights.... It also involves self-definition, affirmation, and empowerment" ( $p$. 262).

Significant work exists exploring the duality of citizenship and how different communities and societies have adopted communal notions of citizenship. Avoseh (2001) theorized the following about citizenship in African societies:

A communal view of life...is an imperative for active citizenship in traditional African societies. In this view of life, the individual makes conscious efforts to be aware of the existence and interests of others.... (p. 480)

According to this line of thought, active citizenship requires that an individual's actions simultaneously promote and attend to the needs of the community. Avoseh argued that this communal approach to citizenship places humanity at the center of nation building and citizenship.

Knight and Watson (2014) built upon Avoseh's (2001) citizenship framework in their study on African immigrant youths' experiences in the United States in terms of civic learning and engagement. The authors found that the young people learned civics in particularlu situated contexts and through familial and community relationships, both of which led to participatory communal citizenship. Although Avoseh, along with Knight and Watson, used participatory communal citizenship to attend to the experiences of African immigrant youth, community-centered understandings of citizenship and learning can be extended to make sense of how other communities conceptualize and experience citizenship in the United States. The community structure has traditionally been important to African Americans (see Spinner, 1984) and has continued to serve as a site of strength and camaraderie.

\section{Citizenship Education in the Classroom}

Educational scholars and teachers continue to present new ways of transforming teaching and the curriculum to value the cultural communities of students and to incorporate multiple perspectives and understandings of citizenship in their classrooms (Banks, 2002; Barton \& Levstik, 2004; LadsonBillings, 2009; Pang \& Gibson, 2001). Dilworth (2004, 2008) introduced the notion of multicultural citizenship education as a framework for integrating multiple notions of citizenship into the social studies classroom. She defined multicultural citizenship education as a communal task for teachers and students 
to critically examine the curriculum and their lives through multiple perspectives. Multicultural citizenship education involves helping students acquire the knowledge, skills, and values to succeed in an increasingly global society (Banks, 2008). This means engaging in community building through dialogue and deliberation to solve political issues and social problems and combating assimilationist notions of citizenship to legitimize the rights of citizens to hold allegiances to both their cultural and political communities (Banks, 2008; Dilworth, 2008). It is crucial that teachers teach their students to recognize, name, and take action against the structural issues that affect their lives and their community.

African American women teachers come from a historic tradition of being able to resist the subjugation that permeated the school and other social structures while simultaneously preparing students to become activist citizens. Black women teachers have used their experiences of fighting for social justice to inform how they taught activist notions of citizenship to African American youth (see Harley, 1996; Murray, 2012). The existing research on Black women teachers shows that contemporary educators share many of the same views of teaching as their predecessors. Scholars have documented the multiple ways that African American women teachers understand the political nature of teaching (Knight, 2004) and adapt their curriculum and pedagogy in a way that they believe is best for their students (Beauboeuf-Lafontant, 2005; Dixson \& Dingus, 2008; Gordon, 1985; Thompson, 1998). These teachers have found ways to circumvent the curriculum that aid in the development of intelligent, critically conscious, and community-centered citizens.

Thompson (1998) used a Black feminist ethic of caring (Collins, 2009) to conceptualize how African American women teachers practice caring as a way to uplift their community. For example, a number of scholars have theorized about the well-known practice of "othermothering" (Beauboeuf-Lafontant, 2005; Dixson \& Dingus, 2008), which is described as a feeling of shared responsibility in the social and emotional development of all children in a community. Irvine reported that othermothering involved teachers' essentially "adopting" all students and treating them as if they were their own. But upon further examination, othermothering can be seen as communal childrearing and a form of community uplift. This model of caring and childrearing creates a woman-centered "fictive kin" (Stack, 1974) network of women engaged in the communal practice of raising future citizens, which represents a challenge to conventional models of childrearing. African American teachers in the research literature, both in the past and present, have been known to utilize an ethic of caring in their ability to go above and beyond in their role of educating each African American student to "reach his or her highest potential" (Walker, 1996, p. 158).

\section{Methodology}

In conducting this qualitative multiple case study (Merriam, 2009), I sought to understand in many ways in which African American women teachers 
conceptualize and teach notions of citizenship. I suggest that as a result of their identities as African American women, they choose to utilize a critical approach to citizenship that counters traditional understandings of citizenship. I purposely chose to work with this population of teachers not only because of their absence in the existing literature in the social studies, but also because of my own positionality as a biracial (African American/White) woman and background as a former public school social studies teacher. In this study I located three African American women secondary school social studies teachers to serve as my cases. By studying African American women, this research seeks to illuminate how teachers are drawing on multiple sources of knowledge and ways of knowing in how they enact citizenship education. This study could also help lead to a more inclusive understanding of citizenship that would begin to mirror the diversity seen in American classrooms.

This research study occurred in the spring of 2014. The teachers highlighted in this study all taught in a suburban school district, located in a large state in the southwestern United States. This study was conducted in Denalli Independent School District (DHS) (pseudonym), located in the city of Denalli (pseudonym). This city was purposely selected because it is a majority-minority community with an administrative and teaching force that is predominately African American.

Lorena Harris (pseudonym) is a young African American woman who has served as a teacher at DHS for seven years. At the time of this study, she taught economics and Advanced Placement micro/macro economics to high school seniors. What is unique about Ms. Harris is that she was a 1999 graduate of DHS and is currently an active member of the Denalli community. Zaire Edward (pseudonym) is a tall and very composed African American woman who taught in Denalli schools for 10 years. At the time of the study, she taught 11th grade United States history. Ms. Edward also lives in the Denalli community with her three children who attend Denalli elementary, middle, and high schools. Ranisha Boyd (pseudonym) has over 25 years of public school teaching experience. This was her fifth year teaching ninth grade world geography at DHS. While Mrs. Boyd had spent only a short amount of time as a teacher at DHS, she has been a member of the Denalli community for nearly 20 years.

The data I collected from this study included observation and interview notes, interview transcripts, and artifacts from the three participants' classrooms. During my semi-structured interviews with each participant, we spoke about a variety of topics such as why each woman wanted to become a teacher, what their own social studies experiences were like as K-12 students, and what each woman considered to be the purpose of social studies, as well as how they understood and taught the notion of citizenship. After the interviews I manually coded the interview transcripts and analyzed them as Miles, Hubberman, and Saldaña (2013) suggest by noting patterns and themes, arriving at comparisons and contrasts and determining conceptual explanations of the study. This process allowed me not only to organize the data, but also to perform a crosscase analysis. I also member-checked and conducted follow-up interviews with 
my participants as Merriam (2009) suggests, confirming the emerging themes. The patterns, themes, and comparisons of the data led me to the findings included in this paper.

\section{Emerging Themes}

From the analysis of the data I found that although the three participants were cognizant of the dominant definition of citizenship, as membership to the nation-state as well as the performative aspects of citizenship, these women refused to accept or teach this understanding of citizenship because of its failure to incorporate African Americans' past and present experiences of civic estrangement (Tillet, 2012). The first theme showed that the participants believed that feeling a sense of belonging to a particular community was a fundamental component of citizenship. The second theme demonstrated that an integral aspect of community membership was finding ways to care about and uplift that community. Finally, developing a strong cultural identity, the third theme, was central to the way in which they felt part of the community.

\section{Conceptualizing Communal Citizenship}

When asked how the teachers would describe their ideal definition of citizenship - that is, in a way that aligned with their experiences and those of their students-all three women described a citizenship that involved people experiencing a sense of belonging to a particular community. Freshman world geography teacher Mrs. Ranisha Boyd cited human nature as a way to describe how society should think about citizenship. She stated, "I think man always had a sense of belonging...even in early civilizations, they had a sense of citizenship" (Boyd interview, 05/27/14). Mrs. Boyd made a connection between citizenship and humans' desire to experience a sense of belonging that has been present since the beginning of time (Yuval-Davis, 2006). Mrs. Boyd thought of citizenship in terms of a relational sense of belonging. Hall and Held (1990) and Yuval-Davis (2006) argue that feeling a sense of belonging as citizens was particularly important for those who have been marginalized in society and positioned outside of citizenship. For centuries, citizenship has been a construct controlled by those in power and used as a way to exclude certain bodies from attaining citizenship status and rights. For those who were excluded, their desire was to be included and to have an active role in the nation-state.

Junior American history teacher Ms. Zaire Edward cited her experience as a member of her sorority as a way that she preferred to think about citizenship (Edward interview, 08/19/14). When asked what she valued about her membership in her sorority, she said that she appreciated the sisterhood aspect and that she felt a camaraderie with her sorority sisters-a sense that was built in part by serving others and giving back to the community (Edward interview, 
08/19/14). She acknowledged that she shared with her students about her sorority membership as a way to teach about community, service, and contributing to society: "I like to share community service stories that I complete with my sorority. I also emphasize to students joining a fraternity/sorority is more than step-shows ${ }^{2}$; however, it is about a sense of community and service" (Edward interview, 08/19/14). To Ms. Edward, ideal notions of citizenship were very much like her relationship with her sorority sisters.

In particular, Ms. Edward mentioned that "sisterhood" was essential to how she viewed herself as a citizen in that particular community. Ms. Edward's sorority gave her a community and "sisters" that offered her companionship and an opportunity to experience citizenship. Black women's relationships with one another, in both formal and informal organizations, offer opportunities to "affirm one another's humanity, specialness, and right to exist" (Collins, 2009, p. 113). Women-centered networks and "fictive kin" relationships (Stack, 1974) offer Black women a community of support and uplift as well as a space to collectively cope and resist oppression (Collins, 2009). When describing what citizenship meant to her personally, Ms. Edward described a fictive kin network of support and uplift. Citizenship, Ms. Edward believed, should provide that same sense of belonging, support, and uplift. Moreover, an important part of her affiliation with that community was engaging in community service. This suggests that in exchange for membership and a sense of sisterhood, service was an expectation and responsibility for her (as a member). Through her membership in her sorority, Ms. Edward was able to view citizenship as communal and not just as being an individual entity. Community is often characterized as a feeling of companionship with others as a result of shared attitudes, interests, and goals. Members of a community often develop relationships with others that create a sense of belonging to that group and space.

Senior economics teacher Ms. Lorena Harris was a bit more direct in rejecting the White-stream definition of citizenship as membership to the nationstate premised on blind patriotism and individualism. Similarly to the other three participants, she also described a communal understanding of citizenship:

When I look at the dictionary definition of citizenship I don't really define it that way myself. To me, that isn't really all that citizenship is.... Because to me, I worry about my community and that's pretty much it. I do get concerned especially because we're so focused on things at the individual level too much instead of community. (Harris interview, 05/23/14)

Ms. Harris rejected the traditional individualistic and national construct of citizenship and instead preferred to define citizenship at the communal levelbecause she valued her community. In agreement with Spinner's (1984) critique of citizenship, Ms. Harris criticized the notion of citizenship and dominant societal values because it encourages people to adopt individualistic attitudes and dispositions where citizens are ignorant of how individual and structural decisions, actions, and policies affect the community. In Avoseh's (2001) framework on citizenship in African societies, he wrote that individuals developed a communal perspective on life and that active citizenship grew out of each 
person's being conscious of the existence of others and of how their actions affected others in the community. Ms. Harris's perspective of citizenship was similar to Avoseh's in that she was attempting to move beyond individualistic perspectives on citizenship into one that is based not only on community but also on the relationships between people in the community.

Ms. Harris described a communal framework of citizenship and how it looked in her own life and community:

I'm very into like the collective idea where my kids are your kids and I do feel like a lot of the teachers and parents here are like that kid is also my kid.... An active member of my community doesn't mean I just vote, but actually I go out you know, not just at my school but I know what's going on in the community.... It also means that you know the people in the community. (Harris interview, 05/19/2014)

Ms. Harris appreciated the sense of caring that was present throughout the community and that everyone looked out for each other. This demonstrates an example of active citizenship where humanity is at the center of citizenship and being a citizen involves caring about others and the civil interactions between individuals in a community (Avoseh, 2001). Moreover, Ms. Harris believed that the practice of collective child rearing was present in the school and surrounding community in the way the teachers, administrators, and parents took care of the students. While Ms. Harris described this practice as "collective child rearing," in essence she viewed her role as a teacher as that of being an othermother (Beauboeuf-Lafontant, 2002; Collins, 2009; Dixson \& Dingus, 2008; Foster, 1993). Ms. Harris continued the tradition of teaching and valuing community as a site of citizenship. By discussing collective childrearing as an enactment of citizenship, she was asserting the importance of relationships as a fundamental component of citizenship. Ms. Harris's understanding of citizenship included being active and participating in the community, as well as the relational aspects. This was comparable to Ms. Edward's description of citizenship in that their definitions were community-centered and they privileged relationships with fellow members/citizens and participation in community events.

\section{Teaching Community-centered Citizenship}

Because communal-centered citizenship is premised on developing a sense of belonging, it can also be seen as a form of active citizenship (Flores, 1997b). Active citizenship goes beyond merely acknowledging communal membership; it includes actively working to uplift and serve that community. While it is important for social studies teachers to conceptualize more critical notions of citizenship, their ideas must be translated into practice in order to challenge mainstream discourses of citizenship. The three participants in this study found different ways to integrate and teach communal notions of citizenship into their lessons and classroom discussions. 
Ms. Harris noted that she used her bell ringer warm-ups as a way to teach students lessons about their community and their roles as citizens. She believed that students should know about community events but, more importantly, how what was happening in the mainstream news (e.g., political, economic, and social policies) could affect their community. In order to facilitate those conversations, Ms. Harris regularly integrated current events into her classroom as way to encourage students to learn about the world around them and how policies and actions affect their lives and the community. For example, she once led a discussion about the protests that were occurring throughout the United States by Wal-Mart employees calling for a living wage. She felt that this was an important event because there was a Wal-Mart where a number of students and their families worked less than two miles from the school. She stated,

So I had to explain that to them [the students] that when you're shopping just because Wal-Mart is one of those big stores, think about what its presence means to the people in a community. I was like, before you say, "I love Wal-Mart because Wal-Mart has these low prices," why does WalMart have a low price? Don't just like assume that Wal-Mart is cheap but also ask, why can they be so cheap? What do they do to the stores in the community when they come in? So, those are discussions that I try to have with them as it relates to citizenship. (Harris interview, 05/19/14)

Ms. Harris used discussion as a way for students to examine the social, political, and economic realities of the world they inhabit and structural forces that impact their community. Ms. Harris initially noted that her students' first reaction was to think about their own lives, and she wanted them to take a step back and think about the effect that a structure (such as Wal-Mart) had on the community entity and its citizens. Ms. Harris was teaching students not only about moving away from seeing citizenship as individualism but also about embracing the role of citizens who recognize and critique structures that affect the well-being of their African American and Latina/o community. Similarly, Ms. Harris taught her students a form of citizenship that was rooted in a critical examination of the structures that disadvantage communities and their workers, but she also helped her students to develop an awareness of how to take action against such structures as consumers (Dilworth, 2008). By framing the current event around the effect a structure has on a community of color, Ms. Harris was teaching active citizenship (Avoseh, 2001) as being cognizant of how an individual's actions must simultaneously promote and attend to the needs of the community.

I witnessed several instances where Ms. Edward integrated her own understanding of communal citizenship into her classroom. Because Ms. Edward stated that she valued the service aspect of belonging to a community (in reference to her sorority membership), she incorporated service and contributing to society as important components of her leadership unit. ${ }^{3}$ One lesson I observed had students examine the connection between community service and citizenship. Ms. Edward began the lesson by discussing how leaders sought to contribute to society and how community service was an essential part of leadership: 
So how can you make a mark in a culturally diverse society? How can you make a mark as citizens? It can begin with community service. You can start off with community service and you can expand and do bigger things as you get older... and you can contribute back to society...that is one way it is really important to contribute back to the community and think beyond yourself. (Edward classroom observation, 05/22/14)

Ms. Edward stressed the importance of a citizen engaging in community service as a way to make a difference in their community. Similar to Ms. Harris, Ms. Edward attempted to teach active citizenship (Avoseh, 2001) and frame leadership as premised on the responsibility and duty to serve others. Ms. Edward valued community service as an essential component of participatory communal citizenship and therefore explicitly made the connection between leadership, citizenship, and community service.

Ms. Edward drew from her own experience in her sorority to craft an understanding of citizenship that valued giving back to that particular African American and Latina/o community (Denalli). Moreover, this notion of service to the community was rooted in notions of fictive kinship (Stack, 1974) and sisterhood from her sorority. Because of the raced and gendered aspect of her participation with her sorority, it represented the long tradition of Black women's organization work in activism and community uplift as citizenship (Brown, 2006; Collins, 2009). Therefore, the notion of service was thought of as a way to uplift the Denalli community. Ms. Edward's lessons on leaders/citizens engaging in community service were reminiscent of the historic practice of Black women's work in racial/community uplift.

The emphasis on creating a class community was apparent in Mrs. Boyd's class from the moment I first walked into her classroom. Because Mrs. Boyd defined citizenship in terms of the civil sense of belonging to a group, she took steps to ensure that each student felt part of their class community. To do this, Mrs. Boyd implemented a policy that encouraged civility and the expectation that students must treat one another with kindness and respect. If a student insulted another student or the teacher, then that student had to give the person they had offended two compliments. I was able to witness this policy towards the end of one class when students were presenting their Southeast Asia projects.

Maria (pseudonym) presents her drawing of two cultural symbols that represented Southeast Asia to the class.

Isaiah (pseudonym) laughs at Maria's drawing.

Mrs. Boyd: Oh no, you know what that means! Class, what does it mean?

Class: He gotta give her two-ups! ${ }^{4}$

Mrs. Boyd: You gotta tell her two compliments.

Mrs. Boyd attempted to create a safe and supportive community environment in her classroom. The students belonged to a community culture where they were able to feel safe and learn to treat each other with respect and civility. The exchange represented a disruption in the class community when Isaiah laughed 
at Maria's drawing. In order to heal the class community, Mrs. Boyd's policy of two compliments after a moment of disrespect was an effort to encourage community building and make sure that everyone felt part of their class community. This situation illustrated that, to Mrs. Boyd, citizenship was more than the acquisition of civic knowledge or membership to the nation-state; citizenship involved sustaining relationships within a community and the duty of citizens to enact critical caring in their interactions with other individuals in the community, all done in an effort to build a strong sense of community.

\section{Cultural Community Citizenship}

The participants in this study recognized culture and community as essential components of citizenship. Each teacher found ways to purposely teach students to recognize culture as a natural part of the human existence and was central to who we are as citizens. One project for Mrs. Boyd's ninth grade students required the creation of "micro societies." ${ }^{5}$ One of the first steps of building a micro society was that the students needed to create a governing body, which included the writing of a Bill of Rights. Mrs. Boyd stressed the importance of the students' creating the Bill of Rights because it represented the rights that the citizens felt were fundamental to their existence as human beings in the community and that the government must not infringe upon (Boyd interview, 05/27/14). The micro society Bill of Rights created by the student governing body listed rights such as the "right to keep beliefs" and the "right to be cultural beings" (Boyd classroom artifact, 05/29/14). The students in Mrs. Boyd's micro society were performing notions of cultural citizenship because they found it necessary to include in their Bill of Rights the right for citizens to maintain their cultural communal beliefs and identities, which they considered necessary to their existence as citizens in their micro society community. By adding cultural communal rights into their Bill of Rights, the students asserted that these rights were important to their community identity and charged the government to respect and protect those rights in exchange for their allegiance.

Ms. Harris also noted that culture and cultural identity united students in the Denalli school community and were vital to how students viewed themselves as citizens. For example, observing the behavior of students during school assemblies made her realize that Denalli students did not feel compelled to adhere to traditional "patriotic" exhibitions of citizenship to the nation-state. Instead, she believed Denalli students valued the different cultural identities and memberships represented in the community as legitimate manifestations of citizenship.

I don't think our kids buy into patriotic displays of citizenship. Like, if we're doing the pledge or something, we got kids on the phone and I'll tell my kids, "You're supposed to take your hat off," but like they don't care. Some of them either had phones, some were laughing and playing around, but it's very different when we have cultural assemblies... like we used to have 
a Cinco de Mayo kind of program, like they'll sit and listen to that, and I think like their citizenship is defined here [at DHS] more by where you fit in culturally. Because it's not so much that patriotism idea, even though that's I think what the American idea of citizenship is. But I think for our kids it's more of a cultural type of citizenship. It's being a part of a group culture is their citizenship membership.... Because this is a predominantly Black school, and the kids, they're really good about embracing each other...l've never seen anyone be afraid to express their culture, who they are, or where they're from. (Harris interview, 05/23/14)

Ms. Harris observed that her students engaged in acts of resistance to traditional or White-stream displays of citizenship by refusing to participate in patriotic performances of citizenship. Ms. Harris's numerous statements and observations suggest that she believed that her students were cognizant that different cultures and cultural beliefs were not valued in the mainstream discourse on citizenship and therefore refused to engage in traditional performance of citizenship as a form of resistance. Students expressed cultural solidarity with their own cultural group and others who were also marginalized in public political spaces. Because these students supported the cultural performance of the Cinco de Mayo program, this was an example of students viewing citizenship as culturally based and rooted in forging a community where different cultural groups experienced a sense of belonging and recognition (Flores, 1997b).

Ms. Harris believed that because Denalli was a predominantly African American and Latina/o school and community, the people enacted the notion that citizens (both in the school and in the surrounding community) had the right to maintain their cultural identity and beliefs. The students felt comfortable embracing their cultural identity in that space because they recognized culture as a uniting entity that was central to how they viewed themselves as citizens. Flores (1997a) believed that cultural performance was linked to cultural citizenship because it forged a collective sense of community and belonging that was shared by multiple people. The cultural performance can be seen as a vehicle to utilize culture and history to experience solidarity and pride with the community. Moreover, cultural citizenship is a form of resistance because it produces a collective sense of self that builds solidarity in communities of color. Flores (1997a) suggested that "this aspect of cultural citizenship takes seriously a community's efforts, whether conscious or not, to exert their own particular sense of self through cultural practice since these efforts are the foundation for any common action" (p. 150). Cultural identity and cultural performances were ways that Denalli students expressed solidarity and uplift as a community. Their cultural communal understanding of citizenship fostered solidarity and strength within the Denalli community. 


\section{Discussion and Recommendations}

Yuval-Davis (2006) and Hall and Held (1990) argue that modern-day citizenship entails deciding who belongs in the nation-state and what signifies belonging. The notion of belonging represents an emotional attachment and feelings of being "safe" and "at home." The cultural community represents a safe and legitimate space to exist as citizens-both to their cultural community and the nation-state. The community serves as an important site of solidarity and resistance in the struggle for citizenship for African Americans because it gives them a space to enact understandings of citizenship that align with their own cultural and communal history and knowledge.

While the African American women participants in this study, at times, drew on cultural (Flores, 1997a, 1997b; Rosaldo, 1994, 1997), active (Avoseh, 2001), and participatory communal (Knight \& Watson, 2014) notions of citizenship, their understanding and teaching of citizenship was shaped largely by their epistemological standpoint as African American women in how they conceptualized citizenship as (a) relational by creating a space where individuals experienced a sense of belonging; (b) uplifting by dedicating themselves to the betterment and empowerment of the Black community; and (c) universal by experiencing in multiple situations and contexts. The ways in which African American women described citizenship were based on the raced and gendered notions of sisterhood and collective childrearing/othermothering (Collins, 2009; Foster, 1993, 1997). Thompson (1998) believed that it is important to view the practice of othermothering not solely in terms of caring for children, but rather as a way to sustain adult and community relationships. These fictive kin relationships (Stack, 1974) create a space of community support and resistance when faced with oppression (Collins, 2009).

By conceptualizing citizenship as relational, the participants reasserted relationships, people, and humanity as fundamental components of citizenship (Collins, 2009). Because citizenship could be seen in terms of the relationships forged in fictive kin communities, citizenship could be experienced in school, communal, and familial spaces. Knight and Watson (2014) described a participatory communal notion of citizenship in which outside school spaces were seen as valid sites of citizenship. In these spaces, civic knowledge could be learned in particularly situated contexts and through interactions with family and community members. This view substantiates the premise that different forms of community (such as classroom, family, school, culture, or nation-state) can be seen as sites of citizenship.

The data analysis presented in this research study confirms that African American women teachers conceptualize and teach critical notions of citizenship that align with their identities and their community. We know that critical perspectives of citizenship are largely absent from citizenship education found in public schools. This recommendation calls for the social studies curriculum to be 
more inclusive in defining citizenship as taught in K-12 schools. Citizenship education must embrace and celebrate notions of difference as an important part of what it means to be an American citizen. Moreover, it is also important to recognize that one can experience citizenship in multiple spaces and to multiple nations, and that does not detract from their allegiance to the United States. It is imperative that schools enacting citizenship education accept students' multifaceted citizenship to different nation-states or their cultural/ethnic or religious communities. Doing this would create a more inclusive environment that allows different communities finally to feel a sense of belonging.

\section{Notes}

1. The term African American and Black will be used interchangeably. Selfidentity is very personal, so it is important to ask an African American/Black woman how she identifies herself and not to make assumptions.

2. A performance that features a group (or individuals) dancing while using their bodies as instruments (see Fine, 2003; Hastie, Buchanan, \& Martin, 2006; Ross, 2001).

3. The leadership unit in her U.S. history course was taught the last month of the school year and was an opportunity for students to learn about their future roles as African American and Latina/o leaders. Ms. Edward designed the leadership unit using her own life experiences as well as content from a graduate course she took on leadership. She was purposeful in the fact that she wanted to make the curriculum relevant to the lives of students and create a space where students, whose voices are typically silenced, had the opportunity to be heard.

4. "Two ups" meant the student had to give two compliments.

5. MicroSociety, Inc. is a non-profit program in schools that encourages students to apply classroom knowledge to real world scenarios through the creation of a micro-society where students create governing bodies and become entrepreneurs. By participating in the micro societies, the students learn and practice twenty-first century skills in the classroom by managing their own miniature community for one period a day.

\section{References}

Avoseh, M. B. M. (2001). Learning to be active citizens: Lessons of traditional Africa for lifelong learning. International Journal of Lifelong Education, 20(5), 479-486.

Banks, J. A. (2002). An introduction to multicultural education (3rd ed.). Boston, MA: Allyn and Bacon.

Banks, J. A. (2008). Diversity and citizenship education in global times. In J. Arthur, I. Davies, \& C. Hahn (Eds.). The Sage handbook of education for 
citizenship and democracy (pp. 57-70). Los Angeles, CA: Sage Publications.

Barton, K., \& Levstik, L. (2004). Teaching history for the common good. New York, NY: Routledge.

Beauboeuf-Lafontant, T. (2002). A Womanist experience of caring: Understanding the pedagogy of exemplary Black women teachers. The Urban Review, 34(1), 71-86.

Beauboeuf-Lafontant, T. (2005). Womanist lessons for reinventing teaching. Journal of Teacher Education, 56(5), 436-445.

Brown, N. (2006). Private politics \& public voices: Black women's activism from World War I to the New Deal. Bloomington, IN: Indiana University Press.

Collins, P. H. (2009). Black feminist thought: Knowledge, consciousness and the politics of empowerment. New York, NY: Routledge.

Dilworth, P. (2004). Multicultural citizenship education: Case studies from social studies classrooms. Theory and Research in Social Education, 32(2), 153186.

Dilworth, P. (2008). Multicultural citizenship education. In J. Arthur, I. Davies, \& C. Hahn (Eds.). The Sage handbook of education for citizenship and democracy (pp. 424-437). Los Angeles, CA: Sage Publications.

Dixson, A., \& Dingus, J. (2008). In search of our mothers' gardens: Black women teachers and professional socialization. Teachers College Record, 110(4), 805-837.

DuBois, W. E. B. (1994). The souls of Black folk. New York, NY: Dover Thrift Editions.

Fine, E. C. (2003). Soulstepping: African American step shows. Champaign, IL: University of Illinois Press.

Flores, R. R. (1997a). Aesthetic process and cultural citizenship: The remembering of a social body in San Antonio. In W. V. Flores \& R. Benmayor (Eds.). Latino cultural citizenship: Claiming identity, space, and rights (pp. 124-151). Boston, MA: Beacon Press.

Flores, W. V. (1997b). Citizens vs. citizenry: Undocumented immigrants and Latino cultural citizenship. In W.V. Flores, \& R. Benmayor, R. (Eds.). Latino cultural citizenship: Claiming identity, space, and rights (pp. 255277). Boston, MA: Beacon Press.

Foster, M. (1993). Educating for competence in community and culture: Exploring views of exemplary African-American teachers. Urban Education, 27(4), 370-394.

Foster, M. (1997). Black teachers on teaching. New York, NY: New Press. 
Gordon, B. M. (1985). Toward emancipation in citizenship education: The case of African American cultural knowledge. Theory and Research in Social Education, 12(4), 1-23.

Hall, S., \& Held, D. (1990). Citizens and citizenship. In S. Hall \& M. Jacques, (Eds.). New times: The changing face of politics in the 1990s (pp. 173188). London, UK: Verso.

Harley, S. (1996). Nannie Helen Burroughs: 'The Black goddess of liberty'. The Journal of Negro History, 81(1), 62-71.

Hastie, P. A., Buchanan, A. M., \& Martin, E. (2006). Stepping out of the norm: An examination of prices for a culturally-relevant pedagogy for African American children. Journal of Curriculum Studies, 38(3), 293-306.

Knight, M. G. (2004). Sensing the urgency: Envisioning a Black humanist vision of care in teacher education. Race Ethnicity and Education, 7(3), 211227.

Knight, M. G., \& Watson, V.W.M. (2014). Toward participatory communal citizenship: Rendering visible the civic teaching, learning, and actions of African immigrant youth and young adults. American Educational Research Journal, 51(3), 539-566.

Ladson-Billings, G. (2009). The Dreamkeepers: Successful teachers of African American children. San Francisco, CA: Jossey-Bass.

Lomawaima, K. T., \& McCarty, T. (2002). When tribal sovereignty challenges democracy: American Indian education and the democratic ideal. American Educational Research Journal, 39(2), 279-305.

Merriam, S. B. (2009). Qualitative research and case study applications in education. San Francisco, CA: Jossey-Bass Publishers.

Miles, M. B., Huberman, M. A., \& Saldaña,, J. (2013). Qualitative data analysis: A methods sourcebook. Los Angeles, CA: Sage Publications.

Mills, C. (1997). The racial contract. New York, NY: Cornell University Press.

Murray, A. D. (2012). Countering the master narrative in U.S. social studies: Nannie Helen Burroughs and new narratives in history education. In C. Woyshner \& C. H. Bohan (Eds.). Histories of social studies and race: 1865-2000 (pp. 99-114). New York, NY: Palgrave Macmillian.

Ong, A. (1996). Cultural citizenship as subject making: Immigrants negotiate racial and cultural boundaries in the United States. Current Anthropology, 37(5), 737-762.

Pang, V., \& Gibson, R. (2001). Concepts of democracy and citizenship: Views of African American teachers. The Social Studies, 96(6), 260-266.

Pateman, C. (1988). The sexual contract. Oxford, UK: Blackwell.

Rosaldo, R. (1994). Cultural citizenship and educational democracy. Cultural Anthropology, 9(3), 402-422. 
Rosaldo, R. (1997). Cultural citizenship, inequality, and multiculturalism. In W. V. Flores \& R. Benmayor, R. (Eds.). Latino cultural citizenship: Claiming identity, space, and rights (pp. 27-38). Boston, MA: Beacon Press.

Rosaldo, R., \& Flores, W.V. (1997). Identity, conflict, and evolving Latino communities: Cultural Citizenship in San Jose, California. In W. V. Flores \& R. Benmajor (Eds.). Latino cultural citizenship: Claiming identity, space, and rights (pp. 57-96). Boston, MA: Beacon Press.

Ross, L. C. (2001). The divine nine: The history of African American fraternities and sororities. New York, NY: Kensington Books.

Spinner, J. (1984). The boundaries of citizenship: Race, ethnicity, and nationalist in the liberal state. Baltimore, MD: Johns Hopkins University Press.

Stack, C. D. (1974). All our kin: Strategies for survival in a Black community. New York, NY: Harris and Row.

Tillet, S. (2012). Sites of slavery: Citizenship and racial democracy in the post Civil Rights imagination. Durham, NC: Duke University Press.

Thompson, A. (1998). Not the color purple: Black feminist lessons for educational caring. Harvard Educational Review, 68(4), 522-555.

Walker, V. S. (1996). Their highest potential: An African American school community in the segregated South. Chapel Hill, NC: University of North Carolina Press.

Yuval-Davis, N. (2006). Belonging and the politics of belonging. Patterns of Prejudice, 40(3), 197-214.

Zinn, H. (2003). A people's history of the United States: 1492-present. New York, NY: Harper Collins.

\section{Author Contact}

Amanda Vickery: Amanda.Vickery@asu.edu

Mary Lou Fulton Teachers College

Arizona State University

1050 S. Forest Mall, Tempe, AZ 85287

Tempe, AZ 85281

U.S. A. 